\title{
AZ INFORMÁLIS TANULÁS SZEREPE AZ ÖNKÉNTES MUNKÁBAN
}

FÉNYES HAJNALKA ${ }^{1}$

Fiona Duguid - Karsten Mündel - David Schugurensky (eds.): Volunteer Work, Informal Learning and Social Action. Sense Publishers: Rotterdam, Boston, Taipei, 2013.

\section{DOl: https://doi.org/10.53585/OnkSzem.2021.3.106-110}

A tanulmánykötet az informális tanulás és az önkéntesség kapcsolatával foglalkozik, amely a Springer kiadó „The Knowledge Economy and Education" sorozatának keretében jelent meg 2013-ban. A sorozat célja a tudásalapú társadalom és az oktatás kapcsolatának elméleti és gyakorlati, avagy szakképzési aspektusainak bemutatása.

A munka hiánypótló, hiszen a szakirodalom elsősorban a formális oktatás és a fizetett munka kapcsolatával, illetve az önkéntességen belül az önkéntesség motivációival és hatásaival foglakozik, és kevés szó esik az informális tanulásról. Azonban napjainkban, a tudásalapú társadalomban, az élethosszig tartó tanulás egyre fontosabbá válik, mely akár az önkéntesség keretében is folyhat.

Szerkezetileg a tizenegy tanulmányt tartalmazó könyv a bevezető részt követően - amelyet a kötet egyik szerkesztője David Schugurensky jegyez - az első fejezetben definíciós kérdésekkel, a másodikban pedig az informális tanulás legfontosabb nemzetközi és kanadai trendjeivel foglalkozik. A könyv fő értéke, hogy az elméleti alapvetések tisztázása után, nyolc esettanulmányon keresztül is bemutatja az informális tanulás és az önkéntes munka kapcsolatát, megvalósulását. Szó van arról, hogy milyen a tanulási folyamat az adott önkéntes munkavégzés során, és milyen hatása van ennek az önkéntesek személyes és szakmai

\footnotetext{
1 Fényes Hajnalka (PhD) közgazdász-szociológus, egyetemi docens, Debreceni Egyetem Szociológia és
} Szociálpolitika Tanszék 
fejlődésére. Az esettanulmányok között vannak szociális szolgáltatásokat nyújtó, a helyi társadalmat reprezentáló és végül a közösségépítést és a társadalmi változást támogató szervezetek is. Emellett, az esettanulmányok közül kettő a kanadai migránsok körében zajló önkéntességgel foglalkozik. Végül pedig az összegző fejezet összehasonlító elemzést mutat be, és gyakorlati javaslatokat fogalmaz meg, valamint szó van a további kutatások lehetséges irányairól is.

\section{AZ ÖNKÉNTESSÉG, MINT AZ INFORMÁLIS TANULÁS SPECIÁLIS TÍPUSA}

A kötet első tanulmánya ${ }^{2}$ az informális tanulás és önkéntesség elméleti alapvetéseivel foglalkozik. A tanulás három formáját különböztetik meg: a formális, a nem-formális és az informális tanulást, ahol az informális tanulás annyiban különbözik a nem-formális tanulástól, hogy az „a mindennapi élet természetes velejárója”, spontán, nem tudatos tanulási folyamat, azaz nem azonosítható a tudatos, tervezett, önálló tanulással. Mindezek után az önkéntességet az informális tanulás egy speciális típusának tekintik a szerzők.

Fontos ide kapcsolódó fogalom a tapasztalati tanulás is, mivel az önkéntesség során általában a „learning by doing” elv érvényesül, azaz a cselekvés közben tanulunk. A tanulmány tanulsága, hogy a tanulás, akár formális akár informális, egyben az önkéntesség motivációja is lehet, melyre eddig kevesen hívták fel a figyelmet. A második fejezetben ${ }^{3}$ Susan Stowe kormányzati szakemberként ad áttekintést az önkéntesség főbb nemzetközi, illetve kanadai trendjeiről, és bemutatja a kanadai, elsősorban formális, szervezetekben dolgozó önkéntesek jellemzőit, valamint kitér a felnőttképzés és informális tanulás trendjeire is Kanadában.

\section{AZ ESETTANULMÁNYOK TANULSÁGAI}

A kanadai vöröskeresztnél végzett interjús kutatásuk alapján írt - a tanulást és a tudásátadást az önkéntességben - elemző tanulmányukban Fiona Duguis és Martha Viveros megállapítják,

\footnotetext{
2 Duguid, Fiona - Mündel, Karsten - Schugurensky, Daniel: Volunteer work and informal learning: A conceptual discussion (pp. 17-36)

${ }^{3}$ Stowe, Susan: Volunteer work and informal learning: Major international and Canadian trends (pp. 37-61)

${ }^{4}$ Duguid, Fiona - Viveros, Martha: Learning and knowledge transfer in volunteering: Exploring the experience of Red Cross volunteers (pp. 63-78)
} 
hogy az önkéntesség motivációja ennél a szervezetnél elsősorban a tradicionális segítő szándék, azonban az itt dolgozó önkéntes fiatalok motivációja az is, hogy a megszerzett tudást későbbi fizetett munkájuk során felhasználhassák, míg az idősebb önkéntesek motivációja, hogy még aktívak maradhassanak a nyugdíjba vonulás után. A megszerzett készségek sokfélék voltak: elsősegélynyújtás, katasztrófa-elhárítás, kommunikációs készségek fejlődése, csapatmunka, vezetői készségek, szociális érzékenység fejlődése. A tanulás általában nem volt tudatos és szándékolt, és elsősorban a tapasztalati tanulás fogalomkörébe volt sorolható.

A második esettanulmány, ${ }^{5}$ - amit Torontói Egyetem felnőttképzéssel és kommunikációfejlesztéssel foglalkozó munkatársa írt - olyan kanadai agrárszakos egyetemistákról szól, akik nyári szünetben mexikói és karibi bevándorlókat tanítottak angol nyelvre, írás- és kommunikációs készségekre, míg a diákok a bevándorlóktól spanyol nyelvet és mezőgazdasági ismereteket tanultak. Ezen önkéntesség érdekessége, hogy egyfajta reciprocitás érvényesült az informális tanulás során, hiszen mindkét fél - segítő és segített - tanult egymástól.

Szintén a bevándorlókkal foglalkozott az az esettanulmány ${ }^{6}$, amely magasan iskolázott bevándorlókat vizsgált, akik azért önkénteskedtek, hogy később megfelelő fizetett munkájuk legyen.

Az önkéntesség munkaerőpiacra való felkészítő szerepe a 2000-es években került előtérbe. Ennek az önkéntesség-típusnak az érdekessége, hogy inkább individualista, mint altruista motivációjú, szemben a tradicionális önkéntességgel. A bevándorlók elsődleges motivációja a nyelvtanulás és a munkatapasztalat-szerzés volt, de fontos számukra az is, hogy megismerjék a kanadai kultúrát, kapcsolatokra tegyenek szert, és javítsák kommunikációs készségeiket. Mindez ötvözve, a formális és informális tanulási módszereken keresztül valósult meg. Érdekes az is, hogy a bevándorlók 70 százaléka nem a szakmájában dolgozott, de a munkatapasztalatszerzés ebben az esetben is fontos motiváció volt és a munkatapasztalataikat fel tudták használni a későbbi álláskeresésük során.

\footnotetext{
5 Perry, J. Adam: Living and learning through solidarity and struggle: Assessing the informal learning of Frontier College Labourer-Teachers (pp. 79-99)

${ }^{6}$ Slade, Bonnie - Luo, Yang Cathy - Schugurensky, Daniel: The experiences of immigrants who volunteer to improve access the labour market: Pushing the boundaries of „volunteerism”. (pp: 101-114)
} 
Két esettanulmányban ${ }^{7}$ a kanadai lakásszövetkezetekről olvashatunk, melyek egyfajta minidemokráciák, ahol az ott dolgozó önkéntesek önkormányzati készségeket és demokráciát tanulnak, miközben „csinálják a demokráciát”. A tanulás ebben az esetben sem tudatos vagy szándékolt. Az önkéntesek saját hibáikból, egymástól és a szemtől szemben való kommunikációból tanulnak. Ezekben a kicsi, demokratikus szervezetekben az önkéntesek megtanulják, hogyan lehetnek jó állampolgárok és döntéshozók, valamint menedzsment és pénzkezelési készségekre is szert tehetnek. A következő esettanulmányban ${ }^{8}$ is az önkéntesek célja, hogy a közösség érdekében tevékenykedjenek, de közben az állampolgári aktivitást is informális és tapasztalati úton - megtanulják, hiszen az önkéntesek itt arról döntenek közösen, hogy hogyan használjanak fel közpénzeket, és ezekkel miként gazdálkodjanak.

Végezetül az utolsó két esettanulmány ${ }^{9}$ egyrészt a közösségi szerveződések, másrészt a társadalmi mozgalmakban dolgozó önkéntesekkel foglalkozik. Az ilyen szervezetekben tevékenykedő önkéntesekre szintén jellemző a kollektív tanulás, de egyben az ügy iránti elkötelezettség is fontos szerepet játszott. A tevékenység során az önkéntesek megtanulták, hogyan kell stratégiát készíteni, kritikusan gondolkozni, együtt cselekedni, illetve megtanulták azt is, hogy van értelme az együttes cselekvésnek, és kisebb közösségek is el tudnak érni közös célokat. Ez a tanulási forma is informális (nem-szándékolt vagy tudatos) és tapasztalati, azaz a cselekvés közben tanultak.

\section{ÖSSZEGZÉS - AVAGY HIÁNYZÓ MAGYAR KUTATÁSOK}

Összességében, az informális és tapasztalati tanulás fókusza miatt a könyv hasznos olvasmány lehet a neveléstudomány iránt érdeklődőknek, de az önkéntesség témaköre és az esettanulmányok sokszínűsége miatt a szociológia és a politikatudomány iránt érdeklődőknek is.

\footnotetext{
7 Duguid, Fiona - Mündel, Karsten - Schugurensky, Daniel: „Learning from each other”: Volunteers' learning in Housing Co-operatives (pp. 115-140) és Behrang, Foroughi - Mccollum, Erica: Learning participatory citizenship: exploring the informal learning of Tenant Volunteers at Toronto Community Housing Corporation (TCHC) (pp. 141-158)

${ }^{8}$ Schugurensky, Daniel: Volunteers for democracy: Informal learning through participatory budgeting (pp. 159176)

9 Mündel, Karsten - Schugurensky, Daniel: Creating healthy communities: The transformative potential of volunteering in community-based organizations (pp. 177-194) és Rogers, Kate - Haggerty, Megan: Learning through volunteering in social movements: The case of Frente Cívico (pp. 195-218)
} 
A könyv hiánypótló, hiszen az önkéntesség hazai szakirodalma alig érinti az önkéntesség és informális tanulás kapcsolatát, illetve mivel a téma a neveléstudomány és szociológia határterülete, a felnőttképzés szakirodalmán belül is ez egy fontos kutatási téma lehetne. A neveléstudományok hozzájárulhatnak, akár módszertanilag is, az önkéntesek képzéséhez akár a formális, akár az informális, nem-szándékolt tanulás vonatkozásában. 